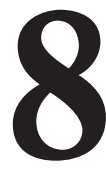

\title{
AUGMENTED REALITY FOR ESL/EFL AND BILINGUAL EDUCATION: AN INTERNATIONAL COMPARISON
}

\author{
(LA REALIDAD AUMENTADA PARA LA ENSEÑANZA DEL INGLÉS Y LA \\ EDUCACIÓN BILINGÜE: ESTUDIO COMPARATIVO INTERNACIONAL)
}

Cristina A. Huertas-Abril

Universidad de Córdoba

Jorge F. Figueroa-Flores

Texas Woman's University, EE.UU.

María Elena Gómez-Parra

Universidad de Córdoba

Emarely Rosa-Dávila

Lisa F. Huffman

Texas Woman's University, EE.UU.

DOI: $10.5944 / e d u c X X 1.28103$

\section{How to reference this article/Cómo referenciar este artículo:}

Huertas-Abril, C.A., Figueroa-Flores, J.F., Gómez-Parra, M.E., Rosa-Dávila, E., \& Huffman, L.F. (2021). Augmented reality for ESL/EFL and bilingual education: an international comparison. Educación XX1, 24(2), 189-208. https://doi.org/10.5944/educXX1.28103

Huertas-Abril, C.A., Figueroa-Flores, J.F., Gómez-Parra, M.E., Rosa-Dávila, E., y Huffman, L.F. (2021). La realidad aumentada para la enseñanza del inglés y la educación bilingüe: estudio comparativo internacional. Educación XX1, 24(2), 189-208. https://doi.org/10.5944/educXX1.28103

\section{ABSTRACT}

In recent decades, educational technologies have enabled new opportunities for teaching and learning on a recurrent basis. In contemporary educational contexts, which are mainly oriented towards active methodologies and studentcentered approaches, educational technologies have led to a significant breakthrough in education. Among emergent educational technologies, it is interesting to specifically highlight the current importance of Augmented Reality (AR), which allows overlaying of virtual objects (that is, 'augmented' elements) into the real world. This paper, after exploring the potential of AR in education, is aimed at comparing pre-service English as a Second Language (ESL), English as a Foreign Language (EFL) and Bilingual Education (BE) teachers' perceptions, uses and preferences $(n=53)$ from two universities (Texas Woman's University, USA, and University of Córdoba, Spain) regarding the use of AR, and analyze 
whether there are similarities and/or differences based on sociocultural context, approaches to education or teacher practices. The findings reveal the positive attitudes towards integrating AR in ESL/EFL and bilingual contexts of the participants of the two institutions. The most noted advantages of AR are that it enhances classroom engagement and its focus is different from traditional teaching methods, increasing student motivation and facilitating their learning processes. Some reported challenges imposed by AR are that access to mobile devices is limiting, the cost of technology, technical issues and the necessity for specialized teacher training. We also found other challenges and numerous advantages of AR usage in ESL/EFL and bilingual contexts, which are discussed thoroughly. Finally, current needs in the field are identified and suggestions are offered for further research in AR for ESL/EFL and BE.

\section{KEYWORDS} reality

Educational technology, bilingual education, teacher training, augmented

\section{RESUMEN}

En las últimas décadas, las tecnologías educativas han facilitado de forma recurrente nuevas oportunidades de enseñanza y aprendizaje. En los contextos educativos contemporáneos, que se orientan principalmente hacia las metodologías activas y donde el alumnado cada vez más es el centro del proceso de aprendizaje, las tecnologías educativas han dado lugar a importantes avances. Entre las tecnologías educativas emergentes, es interesante destacar específicamente la importancia actual de la Realidad Aumentada (RA), que permite superponer objetos virtuales (es decir, elementos "aumentados") al mundo real. Este trabajo, tras explorar el potencial de la RA en educación, tiene como objetivo comparar las percepciones, usos y preferencias de docentes en formación de inglés como segunda lengua (ESL), inglés como lengua extranjera $(\mathrm{EFL})$ y educación bilingüe $(\mathrm{EB})(\mathrm{n}=53)$ de dos universidades (Texas Woman's University, EE. UU., y Universidad de Córdoba, España) en relación con el uso de la RA, y analizar si existen similitudes o diferencias basadas en el contexto sociocultural, los enfoques educativos o las prácticas docentes. Los resultados obtenidos revelan las actitudes positivas de los participantes de las dos instituciones hacia la integración de la RA en los contextos de ESL/EFL y bilingües. Las ventajas más destacadas de la RA son que mejora la participación en el aula y que su enfoque es diferente de los métodos de enseñanza tradicionales, aumentando así la motivación de los estudiantes y facilitando sus procesos de aprendizaje. Algunos de los desafíos encontrados del uso de la RA son la limitación del acceso a los dispositivos móviles, los costes de la tecnología, los problemas técnicos y la necesidad de una formación docente especializada. También encontramos otros desafíos y numerosas ventajas del uso de la RA en 
CRISTINA A. HUERTAS-ABRIL, JORGE F. FIGUEROA-FLORES, MARÍA ELENA GÓMEZ-PARRA, EMARELY ROSA-DÁVILA, LISA F. HUFFMAN

AUGMENTED REALITY FOR ESL/EFL AND BILINGUAL EDUCATION: AN INTERNATIONAL COMPARISON

contextos de ESL/EFL y de EB, que se examinan detalladamente. Finalmente, se identifican las necesidades actuales en este campo y se ofrecen sugerencias para seguir investigando en la RA en contextos de ESL/EFL y EB.

\section{PALABRAS CLAVE}

Tecnología de la educación, enseñanza bilingüe, formación de profesores, realidad aumentada

\section{INTRODUCTION}

Nowadays, in the information society, relevant training is necessary to respond to the presence of technologies, globalization and interconnection in all life spheres. Consequently, in recent years, the emergence of advanced technologies has led to a significant breakthrough in education. In contemporary educational contexts, which are mainly oriented towards active methodologies and student-centered approaches, educational technologies present numerous advantages, together with some challenges, to be borne in mind. Among the challenges, the NMC Horizon Report 2018 (Adams et al., 2018) highlights two key obstacles for higher education: authentic learning experiences and an advanced need to improve digital literacy.

These two challenges can be addressed with a specific type of emergent technology: augmented reality (AR). As Azuma et al. (2001) state, AR allows virtual elements to seem to coexist in the same time and space as objects in real environments. Despite AR allowing teachers to get the best of both worlds (Cabero, \& Barroso, 2016), limited studies show their connections with language learning (Taylor, \& Stone, 2018) and bilingual education (Huertas-Abril, 2020), and scarce are the studies connecting AR with initial teacher training and language and bilingual education.

After exploring the potential of AR in education, this study is aimed at comparing pre-service English as a Second Language (ESL), English as a Foreign Language (EFL) and Bilingual Education (BE) teachers' perceptions, uses and preferences from two universities (Texas Woman's University, USA, and University of Córdoba, Spain) regarding the use of AR, and analyze whether there are similarities and differences based on sociocultural context, approaches to education or teacher practices. More specifically, the following research questions $(\mathrm{RQ})$ are addressed:

RQ1: What are the strengths that pre-service ESL/EFL and bilingual teachers find regarding the integration of AR in the bilingual and ESL/EFL classroom? 
RQ2: What are the limitations that pre-service ESL/EFL and bilingual teachers find regarding the integration of AR in the bilingual and ESL/EFL classroom?

RQ3: Which are the main AR applications that pre-service ESL/EFL and bilingual teachers would integrate in their teaching?

RQ4: What are the similarities in the perceptions of pre-service ESL/EFL and bilingual teachers from TWU and UCO regarding the integration of AR in the bilingual and ESL/EFL classroom?

RQ5: What are the differences in the perceptions of pre-service ESL/EFL and bilingual teachers from TWU and UCO regarding the integration of AR in the bilingual and ESL/EFL classroom?

\section{Theoretical Background}

The increasingly widespread use of Internet-connected mobile devices (e.g. smartphones and tablets) has resulted in a remarkable development of 'alternative realities,' that is, virtual reality (VR), augmented reality (AR) and mixed reality (MR). To address these concepts, Milgram et al. (1995) proposed the reality-virtuality continuum, which ranges from fully real to fully virtual environments (Fig. 1).

Figure 1

Representation of reality-virtuality continuum (Milgram et al., 1995, p. 283)

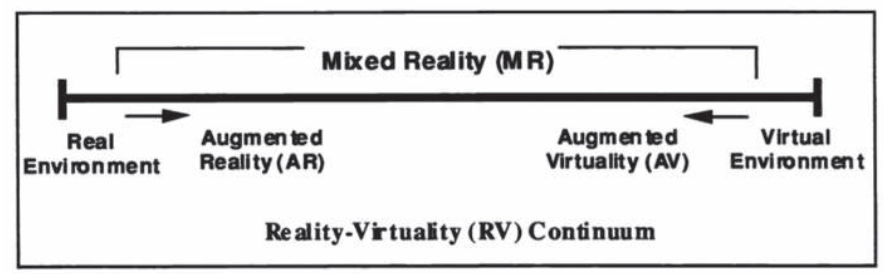

Another interesting continuum was proposed by Klopfer (2008), although this author utilizes the concept of 'augmented reality' in a wider sense - and it could even be assimilated to a 'hybrid reality' (Fig. 2). 
CRISTINA A. HUERTAS-ABRIL, JORGE F. FIGUEROA-FLORES, MARÍA ELENA GÓMEZ-PARRA, EMARELY ROSA-DÁVILA, LISA F. HUFFMAN

\section{Figure 2}

Spectrum of augmented environments by the amount of real-world and virtual input (Klopfer, 2008, p. 93)

\section{Augmented Reality}

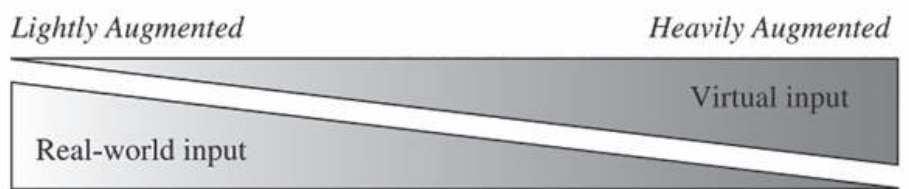

Currently, and considering the popularization of these terms, it can be confusing to include everything under the umbrellas of mixed or augmented reality. Taking into account the previous studies, Huertas-Abril (2020) proposed a real world-virtual world continuum that reflects the burdens of the different types of inputs, considering whether these are real or virtual (Fig. 3).

Figure 3

Real world-virtual world continuum (Translated from Huertas-Abril, 2020)

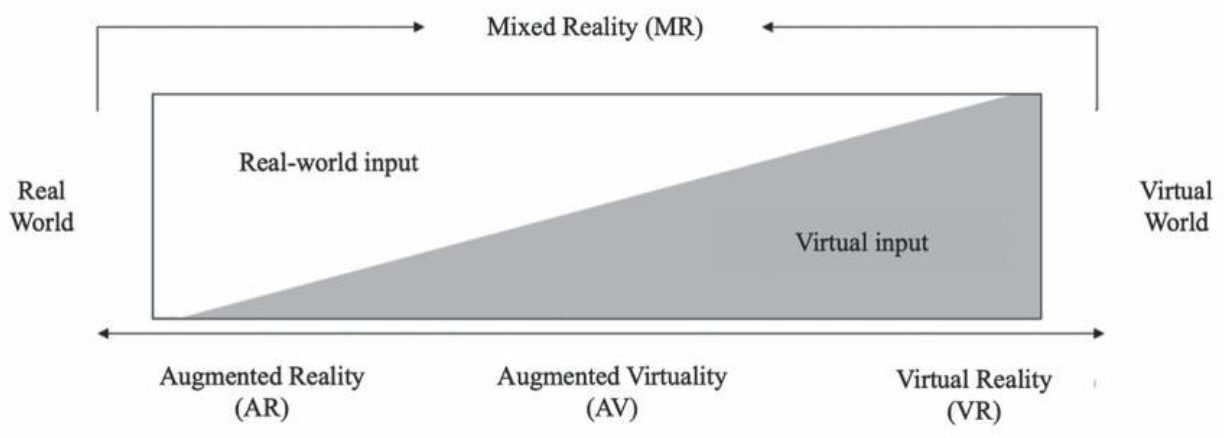

Among these 'realities,' it is interesting to specifically highlight the current importance of Augmented Reality (AR), as it allows the overlaying of virtual objects (that is, 'augmented' elements) into the real world. These virtual objects appear to coexist in the same time and space as real-world objects (Azuma et al., 2001). When combining the real and the virtual worlds, AR creates an enhanced and augmented reality (Klopfer, \& Squire, 2018), stimulating the physical senses and ultimately increasing the information perceived and obtained from the immediate real environment. For this reason, García et al. (2010) emphasized that the adjective 'augmented' is especially adequate for this technology as it amplifies human perception and simplifies the world's multidimensional complexity.

AR was first used in education for potentially dangerous or hazardous contexts, where actual intervention could pose a risk (e.g. surgery or flight instruction). Numerous studies show that AR applications for education have increased dramatically since 2010 (Chen et al., 2017), and even more so in higher 
education (Holland et al., 2020; Vasilevski, \& Birt, 2020). In fact, it is considered an 'important development in educational technology for higher education' with a two to three-year adoption horizon in 2016 (Johnson et al., 2016). Although different approaches can be used to apply AR in education, generally speaking AR should be understood as a digital tool based on the simultaneity between the real and the virtual worlds that allows for the overlapping of 3D virtual objects over real contexts. This consequently enhances real-time interaction and offers additional, contextualized information to increase students' learning experiences (HuertasAbril, 2020).

Nowadays, AR has found widespread use in different subjects and educational contexts. In higher education it is used in numerous contexts, including Medicine Studies (Tang et al., 2020), Architecture and Engineering (Noghabaei et al., 2020) and Education Sciences (Sáez-López et al., 2020), among many others. This increasing application is due to AR allowing: (1) an easier comprehension of complex relations and abstract concepts (Arvanitis et al. 2009); (2) the manipulation of time, position, angles and rotations (Shelton, \& Hedley, 2004); (3) scaffolding (Kerawalla et al., 2006); and (4) the development of different types of competences (Squire, \& Han, 2007), among others. Moreover, other scholars have also accentuated ubiquitous and situated learning as educational affordances of AR applications (Wu et al., 2013), as well as the potential AR has for experiential learning (Niebert et al., 2012).

In this light, Sheehy et al. (2014) identified seven key educational affordances of AR (Fig. 4).

Figure 4

Educational Affordances of Augmented Reality (Sheehy et al., 2014, p. 44)

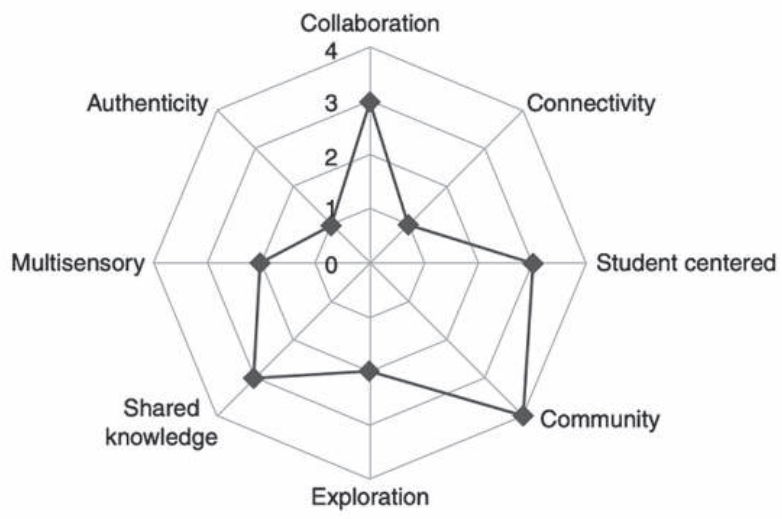

Name of AR system

Key: 4 = Transforms, 3 = Extends, 2 = Supports, $1=$ Impairs, and $0=$ Unknown 
CRISTINA A. HUERTAS-ABRIL, JORGE F. FIGUEROA-FLORES, MARÍA ELENA GÓMEZ-PARRA, EMARELY ROSA-DÁVILA, LISA F. HUFFMAN

AUGMENTED REALITY FOR ESL/EFL AND BILINGUAL EDUCATION: AN INTERNATIONAL COMPARISON

These seven key educational affordances of AR identified by Sheehy et al. (2014) must be understood as follows:

- Collaboration. AR allows educational dialogs to occur in new, different ways and supports collaborative learning in a wider context. AR entails that educational experiences are closer to faceto-face interactions than screen-to-screen ones.

- Connectivity. This entails that AR "makes people and information available directly and quickly. Augmented reality can potentially make this connectivity available at a person's location, wherever this is" (Sheehy et al., 2014, p. 27).

- Student Centered. AR allows the personalization of learning, moving away from structured sequences of activities completed at specific times. AR supports educational experiences that are "highly situated, personal, collaborative and long-term; in other words, truly learner-centered learning" (Naismith et al., 2004, as cited in Sheehy et al., 2014, p. 27).

- Community. AR allows a sense of belonging to a (virtual) community depending on how enjoyable the experience is and what possibilities AR offers for activities and projects away from screen.

- Exploration. AR provides learners with opportunities for problembased learning and exploration with safe environments; however, it must be taken into account that numerous augmented activities tend to be characterized as teacher dominated, thus producing less learner engagement.

- Shared knowledge. Collaborative AR tools allow learners to access and share knowledge in different formats, as they can create or modify materials and share them within communities.

- Multisensory experience. AR tends to be presented as a visual phenomenon, although multisensory experiences can include sound and graphics (Ati et al., 2018) and even haptics, olfactory and gustatory sensations (Sardo et al., 2017).

- Authenticity. Although this term has been defined in several ways, Sheehy et al. (2014) demonstrate a series of interlinked aspects of authenticity in AR, namely: (i) real-life engagement - activity in the physical world mediated by AR; (ii) AR as a real-world activity itself; (iii) AR creating an authentic activity; (iv) AR as a collaborative 
tool; (v) AR mediating a community of practice; (vi) AR supporting a constructivist pedagogy; and (vii) AR supporting personal values and interests.

Finally, and although numerous AR applications are available, there is still a need for educators and teachers to design learning activities specifically for AR (Kesim, \& Ozarslan, 2012) as well as initial teacher training (SaézLópez et al., 2020). To the authors' knowledge, there is limited research on sociocultural aspects affecting the use of AR applications in education, although there are interesting studies on the importance of cross-cultural implications in the use of educational technology (e.g., Dong \& Mertala, 2020) and more specifically in the context of computer-assisted language learning (Tafazoli, et al., 2018). This is particularly relevant in education as when AR applications are designed for specific pedagogical purposes they may foster and strengthen the development of authentic skills and abilities for specific contexts (Schrier, 2006).

\section{Methodology}

\section{Research Design}

Considering the nature of this exploratory research, the study was designed to perform a qualitative analysis following the Qualitative Evaluation Checklist (Patton, 2003). The main purpose of qualitative study is to examine the opinions and experiences of the participants in order to understand and/or interpret the phenomena according to the meaning that the participants attach to them (Denzin, \& Lincoln, 2017, p. 3). For this, the methodological procedure of Grounded Theory (Glaser, \& Strauss, 1967) was used to make a first approach to the phenomenon, as its main aim is to discover or produce a theory from the data collected (Pidgeon, \& Henwood, 1997).

For this study, the authors adopted grounded theory in order to find out categories based on the data collected from the participants regarding AR for the EFL/ESL and bilingual classroom. Then, and according to this framework, we established the stages of the research, from raising research questions to data collection and analysis.

The study sought to compare the perceptions of bilingual and ESL/EFL pre-service teachers from each institution with the strengths and limitations of Augmented Reality (AR) for the classroom, in addition to providing an understanding by comparing the experiences with the use of AR mobile applications. Three structured study questions with identical terminology were given to all the pre-service teachers, guaranteeing that all results were comparable (Bogdan \& Taylor, 1975). The study questions were: 
CRISTINA A. HUERTAS-ABRIL, JORGE F. FIGUEROA-FLORES, MARÍA ELENA GÓMEZ-PARRA, EMAREIY ROSA-DÁVILA, LISA F. HUFFMAN

AUGMENTED REALITY FOR ESL/EFL AND BILINGUAL EDUCATION: AN INTERNATIONAL COMPARISON

Q1: What are the strengths of integrating AR in the bilingual and ESL/EFL classroom?

Q2: What are the limitations of integrating AR in the bilingual and ESL/EFL classroom?

Q3: Which AR applications would you integrate into the bilingual and ESL/EFL classroom?

\section{Participants}

A non-probabilistic sample based on convenience was used for the selection of the participants $(n=53)$. More specifically, the results were obtained from guided reflections made by bilingual and English as a Second Language (ESL) education pre-service teachers from Texas Woman's University (TWU) in Denton, Texas, USA $(\mathrm{n}=27)$, and bilingual and English as a Foreign Language (EFL) education pre-service teachers from the Universidad de Córdoba (UCO) in Córdoba, Spain ( $\mathrm{n}=26)$. A total of $86 \%$ of the pre-service teachers from TWU identified themselves as female, while 13\% identified themselves as male. On the other hand, $73 \%$ of pre-service teachers from UCO identified themselves as female, while $27 \%$ identified as male. The authors conducted this study during the academic year of 2019-2020.

Eligibility criteria were based on proximity and participation in a teaching experience based on the participation in five hours of classroom training with the use of AR. All the participants were selected through criterion referenced (purposive) sampling techniques (Mertens, 2014). For the training, TWU students were provided with iPads and permitted to use their mobile devices and smartphones as the Bring Your Own Device rule (BYOD) was promoted. In the case of UCO pre-service teachers, all of them used their mobile devices and smartphones following the BYOD rule. "BYOD is a practice allowing employees to access company resources for work using personally owned devices (...), and this approach is now having a profound influence in higher education" (Hung, 2016). During the five-hour training, the students were engaged in the use of AR and how to integrate mobile applications in education. More precisely, all of the participants spent time discovering options with different mobile applications and their alignment for the bilingual and ESL/EFL classroom. Besides, the training was supplemented with online resources which included videos, online tutorials and Internet links.

\section{Data Gathering}

For this study, we used a qualitative method and followed an exploratory design. Our theoretical framework was based on Grounded Theory (Glaser, \& 
Strauss, 1967). Grounded Theory sets out to discover or construct theory from systematically obtained data and analyzed using comparative analysis (Chun Tie et al., 2019).

We administered an instrument with 3 open-ended questions in English to pre-service teachers from Texas Woman's University (TWU) and from the Universidad de Córdoba (UCO). The data collection instruments used were guided reflections. Upon five hours of training, all participants were given a worksheet with the study questions to reflect on. The categories were classified into: (i) strengths of AR, (ii) limitations of AR, and (iii) applications and software. After the data was collected, the answers were coded and content analysis was performed to analyze the reflections in order to respond the five research questions posed. This type of analysis is a systematic reading of a body of texts, images and symbolic matter, not necessarily from an author's or user's perspective (Krippendorf, 2004). All responses were coded and gathered by category using NVivo Plus 12 for Windows.

\section{RESULTS}

The categories in the study were (i) strengths of AR, (ii) limitations of AR, and (iii) applications. A total of 332 coded items were obtained from the participants at TWU. On the other hand, at UCO, a total of 298 coded items were obtained.

In the category titled 'strengths of AR', a total of 203 entries were coded at TWU and 185 were coded at UCO. In this category, the bilingual and ESL pre-service teachers from TWU highlighted: (i) enhances classroom engagement with $46 \%$ (93), (ii) motivates students to learn with $28 \%$ (56), (iii) allows fun and new ways to learn with $11 \%$ (23), (iv) promotes a visual learning experience with 9\% (17), (v) lowers the affective filter with $3 \%$ (7), and (vi) it is an inclusive technology with $3 \%$ (7). On the other hand, the bilingual and EFL pre-service teachers from UCO mentioned: (i) the focus is different than with traditional methods of teaching with $22 \%$ (14), (ii) facilitates learning with $20 \%$ (13), (iii) promotes project-based learning with $17 \%$ (11), (iv) enhances manipulative learning with 16\% (10), and (v) supports visual learning with $5 \%$ (3). The positive predisposition of the participants is seen in their opinions below:

Using augmented reality in my bilingual classroom will make students feel more engaged and motivated to learn. This is one of the strengths I see. Students will have the opportunity to participate in a relaxed atmosphere that will lower their affective filter. I believe with AR; all my students will be able to participate. This is one of the most inclusive technologies I've experienced. - Participant 6 (TWU) 
CRISTINA A. HUERTAS-ABRIL, JORGE F. FIGUEROA-FLORES, MARÍA ELENA GÓMEZ-PARRA, EMARELY ROSA-DÁVILA, LISA F. HUFFMAN

AUGMENTED REALITY FOR ESL/EFL AND BILINGUAL EDUCATION: AN INTERNATIONAL COMPARISON

The experience with augmented reality was out of this world. This technology enhances classroom engagement so it's beneficial for emerging bilinguals. Most of all it's fun and inclusive! Everyone in my classroom can get involved and learn. - Participant 13 (TWU)

The advantages of integrating AR could be for introducing new ways of teaching a second language in a more dynamic way so that all students enjoy the learning. - Participant 3 (UCO)

I will use AR to teach Science because I think it is a good way for students to learn different concepts, such as the types of flowers or animals. With this technology, the students will visualize the concepts better and manipulate them. It will help them acquire knowledge. - Participant 19 (UCO)

The study continued with the category 'limitations of AR'. A total of 71 entries were coded for the TWU bilingual and ESL pre-service teachers, and accessibility to mobile devices was perceived as the primary limitation with $46 \%$ (33). Other mentions included: (i) access to the Internet with $25 \%$ (18), (ii) students not able to follow instructions with 14\% (10), (iii) technology setup with $4 \%$ (3), and (iv) teachers not familiarized with the technology with $3 \%$ (2). On the other hand, a total of 61 entries were coded for the UCO bilingual and EFL preservice teachers. They perceived technical difficulties as the biggest limitation, with $45 \%$ (20). Other limitations mentioned included: (i) cost with $36 \%$ (16), (ii) student behavior problems with 9\% (4), and (iii) need for training with 9\% (4). Some of the reflections on the limitations of AR perceived by the participants are expressed below.

It's hard to see limitations with this type of technology, but definitely not everyone has a smartphone or mobile device. Also, there are places in the state where the Internet never arrives. This type of technology needs the support of the Internet and what will happen if we don't have it? - Participant 1(TWU)

Limitations for me include no access to mobile and other technology devices. Not all students have a device, and if the school doesn't provide any, students can be left behind. - Participant 17 (TWU)

Limitations may arise from problems with projected images, and you must have experience in the use of $A R$, because it is not something that you can use from day one. - Participant 3 (UCO)

Technologies can be hard to cope with. Usually, they do not work as we would like them to. Technologies are hard to get for a school. Depending on the context, schools will be able to provide students with electronic devices or not. We need to make sure all of the students are involved in the activity: sometimes students with disabilities or other difficulties cannot get benefit from these kinds. - Participant 8 (UCO) 
The last category found in this study was 'applications.' For this category, 58 items were coded based on the reflections provided by the TWU bilingual and ESL pre-service teachers participating in the study. These participants highlighted the following applications as the ones they would integrate with their bilingual or ESL classrooms: (i) HP Reveal with 50\% (28), (ii) QuiverVision with 21\% (12), (iii) JigSpace with 17\% (10), (iv) StoryFab with 9\% (8), and (v) Augment with 3\% (2). On the other hand, 52 items were coded from UCO's bilingual and EFL preservice teachers' reflections. They perceived (i) QuiverVision with 34\% (18), (ii) JigSpace with 27\% (14), (iii) Chromville with 19\% (10) as the top applications that they would integrate with their bilingual or EFL classrooms. The reflections below present the perceptions of the students in this category.

I loved HP Reveal, and I also enjoyed working and creating a video with JigSpace. My bilingual students will benefit from their existing content. Also, it will be of great support for the teacher. It's easy to work with. I enjoyed the different projects. - Participant 19 (TWU)

I will combine HP Reveal, Quiver and JigSpace. HP Reveal will stimulate the mind of my students. Overall, the onet I liked most was Quiver. I plan to integrate it with my ESL students. I can adjust it to any age, and the visual scaffolding is great. - Participant 23 (TWU)

I prefer to use Quiver because it has many free options to use in class and is very interesting for the students. It is different from the typical activities that are done in class, which is really useful to develop the students' imagination. - Participant 1 (UCO)

Among the different applications, personally the ones I would use in class would be JigSpace, Quiver and Chromville, because these applications do not require much material and are easily accessible from different websites, allowing the class to be taught with just one tablet and projector to show the application on the classroom whiteboard - Participant 5 (UCO)

\section{DISCUSSION}

Teachers' attitudes and beliefs are critical for every teaching and learning situation and are a particularly influential factor in implementing new approaches (Ferreira, \& Kalaja, 2012) and also new technologies in their lessons. In this context, the increase in studies dealing with the didactic potential of AR in different educational settings, from kindergarten (e.g., Lee et al., 2017; Redondo et al., 2020) to higher education (e.g., Teng et al., 2018; Saéz-López et al., 2020), pinpoints the interest that this use of technology is gaining in recent years.

There are numerous opportunities to use AR for educational purposes, and especially for ESL/EFL and bilingual education thanks to the combination 
CRISTINA A. HUERTAS-ABRIL, JORGE F. FIGUEROA-FLORES, MARÍA ELENA GÓMEZ-PARRA, EMARELY ROSA-DÁVILA, LISA F. HUFFMAN

AUGMENTED REALITY FOR ESL/EFL AND BILINGUAL EDUCATION: AN INTERNATIONAL COMPARISON

of real and virtual objects in a real environment. Regarding the findings related to the 'strengths' of AR (Research Question 1), it is striking that TWU students overwhelmingly understand that the two greatest strengths are that AR enhances and improves student participation and motivates them to learn. These results are in line with previous studies that highlight that AR not only increases motivation (Sheehy et al., 2014), but also improves students' performance (Lu, \& Liu, 2015).

It is interesting, however, that UCO students perceived a different approach that happens with AR in contrast to traditional teaching methods, when answering Research Question 5. According to Sharma (2019, p. 16), in the traditional education system there are limitations such as only studying through printed materials that may hinder students' understanding and learning, while "with the help of AR in education, this limitation may be overcome". Moreover, Dalim et al. (2016) emphasize the fact that teaching only from printed images and text is more difficult in comparison to education with AR, as students can learn also with the help of audio, videos and $3 \mathrm{D}$ views. Moreover, adding AR to a 'traditional classroom' allows students to communicate, viewing and interacting with the same virtual object or doing the same activity that is displayed in the real space between them (Sheehy et al., 2014).

Regarding Research Question 4, it is remarkable that the participants from both institutions agree that this technology encourages visual learning. This is especially interesting when learning vocabulary in the ESL/EFL classroom or contents in bilingual education, as visual representations help bridge the gap between complex concepts and unobservable phenomena and the observable world. At the same time, scaffolding takes place thanks to visual support and contextualization of the learning process (Cabero, \& Barroso, 2016). It must be borne in mind, however, that although specialized literature mainly presents AR within education as an essentially visual phenomenon, AR computer-generated sensory input can also be experienced via sound and graphics (Ati et al., 2018), and even haptics, olfactory and gustatory sensations (Sardo et al., 2017).

To answer Research Questions 2, 4 and 5, we find a similarity in the factor of access to technology between the participants of TWU and UCO. It is here that TWU and UCO pre-service teachers understand that access to mobile devices is limiting, a result also observed in previous research (Akçayır, \& Akçayır, 2017). In both cases, it could be understandable since not everyone has a smartphone, a tablet or internet access, which is seen as the main limitation for TWU participants and the second (connected to the cost of technology) for UCO. In the same way, TWU students highlight that not all school districts receive the same amount of money from the state and federal government in the United States of America. Students belonging to the UCO perceived technical difficulties as the most limiting issue (i.e., unstable Internet connection, outdated devices), which is directly connected to the fourth limitation identified by TWU. The necessity of teacher training in AR for ESL/EFL and bilingual education is another key issue shown by participants from both institutions: universities must adapt to changes 
in education and meet the demands of today's society by giving a strong impetus to educational technology in general and to AR in particular to pre-service teacher training (Sáez-López et al., 2020). Unlike TWU, UCO participants were concerned with potential student behavioral problems, including 'addiction' to this type of technology that may lead to refusing other types of activities. Contrary to this perceived limitation, experimental studies have demonstrated that a decreased amount of children's problematic behavior and behavioral dependence can be achieved when taking advantage of the positive impact of AR by helping children to develop healthy digital media usage habits (Shin, \& Gweon, 2020).

Finally, regarding Research Question 3, in the 'applications' category we found a coincidence between the participants of both institutions in the use and recommendation of QuiverVision and JigSpace. The former offers numerous downloadable coloring pages, including some free options, and it even has a specific section for education, which can be especially interesting in ESL/ EFL (e.g., animals, holidays) and bilingual education (e.g., the structure of the cell, volcanoes). QuiverVision's coloring pages can be brought to life thanks to a mobile device and it is available for Android and iOS systems. The latter, however, does not need any type of physical support apart from an iOS mobile device. Jigspace, which is a free app, enhances the learning in English of complex technical, scientific or historical concepts using AR (e.g., Battle of Marathon, manual car transmission, the solar system). A functionality to explore for ESL/ EFL and bilingual education can be Jig Workshop (and its subscription Pro version), where users can import their own 3D models and start creating their AR projects, allowing higher flexibility thanks to tailor-made AR resources. Finally, it is mandatory to mention that TWU students also selected the HP Reveal application, which is no longer available to use, as the one they perceived as the most relevant for implementation, both to use AR resources and to create their own AR materials.

\section{CONCLUSION}

The emergence of AR dates back to the 1990s, but its emergence in educational studies has mainly occurred in the last decade (Akçayır, \& Akçayır, 2017; Chen et al., 2017). AR can be seen as a relatively new technology; however, it is sufficiently mature to be used at schools. With potential technological advances and the decrease of costs for both software and hardware, the introduction of AR technology in education will likely be more widespread in the short and/or medium terms. In this light, AR can potentially support learning and teaching, and can be particularly interesting in ESL/EFL and bilingual education. Despite this situation, research considering pre-service ESL/EFL and bilingual teachers' perceptions and attitudes towards the integration of AR in their classrooms is still limited. 
Our findings show that pre-service ESL/EFL and bilingual education teachers from two different institutions, TWU in the USA and UCO in Spain, have a well-defined positive attitude towards the introduction of AR in their lessons and the number of positive entries regarding strengths (203 and 185, respectively) clearly exceeds that of negative entries or limitations of this technology (71 and 61, respectively). In fact, there are several investigations that show positive results similar to those found in our comparative study (e.g., Cabero, \& Barroso, 2016; Sáez-López et al. 2020). In our case, participants from both universities perceive AR as an emergent technology that can clearly support their teaching performance. The possibility of combining virtual and real objects in a real setting provides both teachers and students with diverse possibilities for teaching and learning in ESL/EFL and bilingual education contexts, at the same time that student motivation (Sheehy et al., 2014) and performance (Lu, \& Liu, 2015) improve. As shown in the findings, AR is also an interesting tool to change 'traditional methodologies,' where this technology may help overcome limitations like restrictions of printed materials and teacher-centered approaches.

As with all educational technologies, however, AR also has some limitations to be considered when using it in education. The most common challenges are linked to the accessibility to mobile devices, costs (as it is not always easy to have sufficient resources) and technical issues, but also to teachers' needs for specialized training, although the pandemic might just change this as online learning becomes more prevalent. Nevertheless, we believe that these challenges can be overcome and these should not be obstacles to the use of AR in ESL/EFL and bilingual classrooms. When technical requirements to use AR are met and specific training for pre-service teachers is consolidated, AR applications can probably be much more frequently used in education at all levels.

The results presented in this paper, however, should be interpreted considering three limitations. First, due to the nature of an exploratory study, only pre-service teachers from two universities from two different countries (TWU in USA and UCO in Spain) were considered as the target population. Therefore, the findings may not be applicable to participants from other institutions, backgrounds or contexts. Future research should then consider recruiting participants from different institutions and sociocultural backgrounds in order to carry out comparisons with this piece of research. Second, the study is only qualitative. Quantitative data could complement the qualitative findings, as it may warrant more potential independent variables. Third, the qualitative findings reported here were only based on self-reported data, so they may be affected by respondents' subjective opinions about the phenomena. For this reason, future studies should also consider obtaining data through additional sources (e.g., observations, tests, questionnaires, interviews, focus groups) in order to obtain more reliable and comparable data.

Future research should consider some key needs derived from the existing findings and gaps of this study. Further research on pre-service teachers' 
opinions about usability and preferences regarding AR in ESL/EFL and bilingual education should be explored in other contexts and institutions. In this light, inservice teachers' and learners' attitudes towards the use of this technology should also be analyzed so that the effects of AR in education could be more thoroughly studied. To facilitate its implementation in real ESL/EFL and bilingual contexts, it would be necessary for researchers to suggest design principles and models that were empirically proven in order to provide teachers with a general framework of use. This would be directly connected to teacher training, another key concern highlighted by the participants in this research: it is time to enhance the use of educational technology in initial teacher training, otherwise it may be extremely difficult to connect pre-service teachers' development with the reality at schools.

\section{ETHICAL STATEMENT}

The authors declare no conflict of interest. The authors declare that the content of this paper presents an accurate account of the work performed as well as an objective discussion of its significance. The authors designed the materials for data collection and informed consent was obtained from the participants, whose responses were collected on a strictly voluntary basis.

\section{ACKNOWLEDGMENT}

Data from TWU was part of the IRB approved research study: Pre-service Teacher Reflections on Augmented and Virtual Reality for the Bilingual and ESL Classroom with \#IRB-FY-2019-141. 


\section{REFERENCES}

Adams, S., Brown, M., Dahlstrom, E., Davis, A., DePaul, K., Diaz, V., \& Pomerantz, J. (2018). NMC Horizon Report: 2018 Higher Education Edition. EDUCAUSE. https://bit.ly/325mllJ

Akçayır, M., \& Akçayır, G. (2017). Advantages and challenges associated with augmented reality for education: A systematic review of the literature. Educational Research Review, 20, 1-11. https://doi.org/10.1016/j. edurev.2016.11.002

Arvanitis, T. N., Petrou, A., Knight, J. F., Savas, S., Sotiriou, S., Gargalakos, M., \& Gialouri, E. (2009). Human factors and qualitative pedagogical evaluation of a mobile augmented reality system for science education used by learners with physical disabilities. Personal and Ubiquitous Computing, 13(3), 243-250. https://doi.org/10.1007/s00779-0070187-7

Ati, M., Kabir, K., Abdullahi, H., \& Ahmed, M. (2018). Augmented reality enhanced computer aided learning for young children. 2018 IEEE Symposium on computer applications \& industrial electronics (ISCAIE), 129-133. https://doi. org/10.1109/ISCAIE.2018.8405457

Azuma, R., Baillot, Y., Behringer, R., Feiner, S., Julier, S., \& MacIntyre, B. (2001). Recent advances in augmented reality. IEEE Computer Graphics and Applications, 21(6), 34-47. https://doi. org/10.1109/38.963459

Bogdan, R. \& Taylor, S. J. (1975). Introduction to Qualitative Research Methods. John Wiley.

Cabero, J., \& Barroso, J. (2016). Ecosistema de aprendizaje con "realidad aumentada": posibilidades educativas. TCE: Tecnología, Ciencia y Educación, 5, 141-154. https://bit.ly/2MZzOs4

Chen, P., Liu, X., Cheng, W., \& Huang, R. (2017). A review of using augmented reality in education from 2011 to 2016 . In E. Popescu, Kinshuk, M. K. Khribi, R. Huang, M. Jemni, N. S. Chen, \& D. G. Sampson (eds.), Innovations in Smart Learning (pp. 13-18). Springer.

Chun Tie, Y., Birks, M., \& Francis, K. (2019) Grounded theory research: a design framework for novice researchers. SAGE Open Medicine, 7, 1-8. https://doi. org/10.1177/2050312118822927

Dalim, C. S. C., Dey, A., Piumsomboon, T., Billinghurst, M., \& Sunar, S. (2016). TeachAR: An interactive augmented reality tool for teaching basic english to non-native children. 2016 IEEE International Symposium on Mixed and Augmented Reality (ISMAR-Adjunct), 82-86. https://doi.org/10.1109/ISMARAdjunct.2016.0046

Denzin, N. K., \& Lincoln, Y. S. (Eds.). (2017). The SAGE handbook of qualitative research $\left(5^{\text {th }} \mathrm{Ed}\right.$.). SAGE Publications.

Dong, C., \& Mertala, P. (2020). Two worlds collide? The role of Chinese traditions and Western influences in Chinese preservice teachers' perceptions of appropriate technology use. British Journal of Educational Technology, 52(1), 288-303.

Ferreira, A. M., \& Kalaja, P. (2012). Beliefs in second language acquisition: Teacher. The Encyclopedia of Applied Linguistics. Wiley Online Library. https://doi. org/10.1002/9781405198431.wbeal0083

García, I., Peña-López, I., Johnson, L., Smith, R., Levine, A., \& Haywood, K. (2010). Informe Horizon: Edición Iberoamericana 2010. The New Media Consortium.

Glaser, B. G., \& Strauss, A. L. (1967). The discovery of grounded theory: strategies for qualitative research. Routledge.

Holland, J. L., Lee, S., Daouk, M., \& Agbaji, D. A. (2020). Higher Education Teaching 
and Learning with Augmented Reality. In E. Alqurashi (Ed.), Handbook of Research on Fostering Student Engagement with Instructional Technology in Higher Education (pp. 229-248). IGI Global.

Huertas-Abril, C. A. (2020). Tecnologías para la educación bilingüe. Peter Lang. https://doi.org/10.3726/b17576

Hung, H.-T. (2016). Clickers in the Flipped Classroom: Bring your own device (BYOD) to promote student learning. Interactive Learning Environments, 25(8), 983-995. https://doi.org/10.1080/1049482 0.2016 .1240090

Johnson, L., Adams Becker, S., Cummins, M., Estrada, V., Freeman, A., \& Hall, C. (2016). NMC Horizon Report: 2016 Higher Education Edition. The New Media Consortium.

Kerawalla, L., Luckin, R., Seljeflot, S., \& Woolard, A. (2006). 'Making It Real': Exploring the potential of augmented reality for teaching primary school science. Virtual Reality, 10(3-4), 163174. https://doi.org/10.1007/s10055-0060036-4

Kesim, M., \& Ozarslan, Y. (2012). Augmented reality in education: current technologies and the potential for education. Procedia-Social and Behavioral Sciences, 47, 297-302. https:// doi.org/10.1016/j.sbspro.2012.06.654

Klopfer, E. (2008). Augmented learning: research and design of mobile educational games. MIT Press.

Klopfer, E., \& Squire, K. (2008). Environmental detectives-The development of an augmented reality platform for environmental simulations. Educational Technology Research and Development, 56(2), 203-228. https://doi. org/10.1007/s11423-007-9037-6

Krippendorff, K. (2004). Content Analysis: An introduction to its methodology ( $2^{\text {nd }}$ ed.). SAGE Publications.
Lee, L. K., Chau, C. H., Chau, C. H., \& Ng, C. T. (2017). Using augmented reality to teach kindergarten students English vocabulary. In 2017 International symposium on educational technology (ISET), 53-57. https://doi.org/10.1109/ iset.2017.20

Lu, S.-J., \& Liu, Y.-C. (2015). Integrating augmented reality technology to enhance children's learning in marine education. Environmental Education Research, 21(4), 525-541. https://doi.org/10.1080/1 3504622.2014.911247

Mertens, D. M. (2014). Research and evaluation in education and psychology: integrating diversity with quantitative, qualitative, and mixed methods. SAGE Publications.

Milgram, P., Takemura, H., Utsumi, A., \& Kishino, F. (1995). Augmented reality: A class of displays on the reality-virtuality continuum. Telemanipulator and Telepresence Technologies, 2351. https:// doi.org/10.1117/12.197321

Niebert, K., Marsch, S., \& Treagust, D. F. (2012). Understanding needs embodiment: a theory-guided reanalysis of the role of metaphors and analogies in understanding science. Science Education, 96(5), 849-877. https://doi. org/10.1002/sce.21026

Noghabaei, M., Heydarian, A., Balali, V., \& Han, K. (2020). Trend analysis on adoption of virtual and augmented reality in the architecture, engineering, and construction industry. Data, 5(1). https://doi.org/10.3390/data5010026

Patton, M. Q. (2003). Qualitative evaluation checklist. https://bit.ly/2DSPDvn

Pidgeon, N., \& Henwood, K. (1997). Using grounded theory in psychological research. In N. Hayes (Ed.), Doing qualitative analysis in Psychology (pp. 245-273). Psychology Press.

Redondo, B., Cózar-Gutiérrez, R., González-Calero, J. A., \& Sánchez Ruiz, R. (2020). Integration of augmented 
reality in the teaching of English as a foreign language in early childhood education. Early Childhood Education Journal, 48(2), 147-155. https://doi. org/10.1007/s10643-019-00999-5

Sáez-López, J. M., Cózar-Gutiérrez, R., González-Calero, J. A., \& Gómez Carrasco, C. J. (2020). Augmented reality in higher education: An evaluation program in initial teacher training. Education Sciences, 10(2), 26. https://doi. org/10.3390/educsci10020026

Sardo, J. D. P., Semião, J., Monteiro, J. M., Pereira, J. A., de Freitas, M. A., Esteves, E., \& Rodrigues, J. M. (2017). Portable device for touch, taste and smell sensations in augmented reality experiences. In A. Mortal, J. Aníbal, J. Monteiro, C. Sequeira, J. Semião, M. Moreira da Silva, \& M. Oliveira (Eds.), Proceedings of the $1^{\text {st }}$ International Congress on Engineering and Sustainability in the XXI Century INCREaSE 2017 (pp. 305-320). Springer. https://doi.org/10.1007/978-3-319-70272$8 \_26$

Schrier, K. (2006). Using augmented reality games to teach 21 st Century Skills. ACM SIGGRAPH 2006 Educators program. https://doi.org/10.1145/1179295.1179311

Sharma, A. (2019). Security issues in the health field with the use of augmented reality [Master's Thesis, Flinders University]. https://bit.ly/3aIHqXn

Sheehy, K., Ferguson R., \& Clough G. (2014). Augmented education: bringing real and virtual learning together. Palgrave Macmillan.

Shelton, B. E., \& Hedley, N. R. (2004). Exploring a cognitive basis for learning spatial relationships with augmented reality. Technology, Instruction, Cognition and Learning, 1(4), 323-357. https://bit.ly/3u3575Y

Shin, H., \& Gweon, G. (2020). Supporting preschoolers' transitions from screen time to screen-free time using augmented reality and encouraging offline leisure activity. Computers in Human Behavior, 105, 106212. https://doi.org/10.1016/j. chb.2019.106212

Tafazoli, D., Gómez-Parra, M. E., \& Huertas-Abril, C. A. (2018). A crosscultural study on the attitudes of English language students towards ComputerAssisted Language Learning. Teaching English with Technology, 18(2), 34-68.

Tang, K. S., Cheng, D. L., Mi, E., \& Greenberg, P. B. (2020). Augmented reality in medical education: a systematic review. Canadian medical education journal, 11(1), e81-e96. https://bit. ly/37dr $1 \mathrm{cU}$

Teng, C. H., Chen, J. Y., \& Chen, Z. H. (2018). Impact of augmented reality on programming language learning: efficiency and perception. Journal of Educational Computing Research, 56(2), 254-271. https://doi. org/10.1177/0735633117706109

Vasilevski, N., \& Birt, J. (2020). Analysing construction student experiences of mobile mixed reality enhanced learning in virtual and augmented reality environments. Research in Learning Technology, 28. https://bit.ly/37fxmEA

Wu, H.-K., Lee, S. W.-Y., Chang, H.Y., \& Liang, J.-C. (2013). Current status, opportunities and challenges of augmented reality in education. Computers \& Education, 62, 41-49. https:// doi.org/10.1016/j.compedu.2012.10.024 


\section{PERFIL ACADÉMICO Y PROFESIONAL DE LOS AUTORES}

Cristina A. Huertas-Abril. ORCID: https://orcid.org/0000-0002-9057-5224

Associate Professor (Profesora Titular de Universidad) at the University of Córdoba (Spain). Department of English and German Studies, Faculty of Education. Her research focuses on Computer Assisted Language Learning (CALL), English as a Foreign Language, Bilingual Education, and Teacher Training. E-mail: cristina.huertas@uco.es

Jorge F. Figueroa-Flores. ORCID: https:/orcid.org/0000-0002-0276-5352

Associate Professor at Texas Woman's University (Texas, USA) Department of Teacher Education, College of Professional Education. His research focuses on Computer Assisted Language Learning (CALL), Emerging Technologies in Education, Bilingual Education, English as a Second Language, Teacher Training, Culturally Relevant Education and Critical Pedagogy. E-mail: jfigueroa2@twu.edu

María Elena Gómez-Parra. ORCID: https://orcid.org/0000-0001-7870-3505

Associate Professor (Profesora Titular de Universidad) at the University of Córdoba (Spain). Department of English and German Studies, Faculty of Education. Her research focuses on Computer Assisted Language Learning (CALL), Bilingual Education, Intercultural Education and Teacher Training. E-mail: elena.gomez@uco.es

Emarely Rosa-Dávila. ORCID: https://orcid.org/0000-0003-1831-1299

Assistant Professor at Texas Woman's University (Texas, USA) Department of Social Work, College of Arts and Sciences. Her research focuses on Community Mental Health, Diversity Education, Microaggressions and Mental Health, Culturally Competent Practice and Virtual Simulated Training. E-mail: ERosaDavila@twu.edu

Lisa F. Huffman. ORCID: https://orcid.org/0000-0002-3409-4397

Dean and Professor at Texas Woman's University (Texas, USA), College of Professional Education. Her research is currently focused on the use of emerging technology in education, teacher training, and the use of cognitive strategies to improve learning. E-mail: LHuffman1@twu.edu

Fecha Recepción del Artículo: 01. Septiembre. 2020

Fecha Modificación del Artículo: 15. Febrero. 2021

Fecha Aceptación del Artículo: 16. Febrero. 2021

Fecha Revisión para Publicación: 25. Febrero. 2021 